\title{
Antibodies to Glutamic Acid Decarboxylase in Australian Children with Insulin-Dependent Diabetes Mellitus and Their First-Degree Relatives
}

\author{
QIAO-YI CHEN, MERRILL J. ROWLEY, GEOFFREY C. BYRNE, TIM W. JONES, \\ TIINAMAIJA TUOMI.' WILLIAM J. KNOWLES, PAUL Z. ZIMMET, AND IAN R. MACKAY \\ Centre for Molecular Biology and Medicine, Monash University, Victoria, Australia IQ.-Y.C., M.J.R., T.T., \\ P.Z.Z., I.R.M.j: the International Diabetes Institute, Caulfield South, Australia [P.Z.Z.]; Princess Margaret \\ Hospital for Children, Subiaco, Western Australia 6008, Australia [G.C.B., T.W.J.J; and Molecular Diagnostics \\ Inc., West Haven, Connecticut 06516 [W.J.K.]
}

\begin{abstract}
Antibodies to glutamic acid decarboxylase (GAD), previously known as the 64-kD pancreatic islet cell autoantigen, are an important serologic marker of insulin-dependent diabetes mellitus (IDDM). Antibodies to GAD (anti-GAD) were examined in sera from Australian children with newly diagnosed IDDM (within 1 mo of diagnosis), IDDM of longer duration (mean $\pm \mathrm{SD}, 4.8 \pm$ $3.3 \mathrm{y}$ ), and in first-degree relatives, using a radioimmunoprecipitation assay with purified porcine brain GAD as antigen. Antibodies to islet cell cytoplasmic antigens (ICAb) were tested concurrently. The frequency of antiGAD was not significantly different in children with newly diagnosed IDDM (31 of $42,74 \%)$ and with IDDM of longer duration (14 of $21,67 \%$ ), whereas ICAb were present more frequently in children with newly diagnosed IDDM $(64 \%)$ than in those with longer duration IDDM (14\%). In all, $90 \%$ of children with newly diagnosed IDDM had either anti-GAD or ICAb, whereas only $\mathbf{4 8 \%}$ had both. For the 77 first-degree relatives, the frequency of antiGAD was $2 \%$ (one of 44 ) in parents and $6 \%$ (two of 33 ) in siblings; ICAb were not detected in any of these relatives. The presence of anti-GAD in the majority of children with IDDM, irrespective of the duration of their disease, represents a useful diagnostic marker for IDDM, and should be of value in ascertaining individuals at risk for developing IDDM. (Pediatr Res 34: 785-790, 1993)
\end{abstract}

\section{Abbreviations}

IDDM, insulin-dependent diabetes mellitus ICAb, antibodies to islet cell cytoplasmic antigens GAD, glutamic acid decarboxylase anti-GAD, antibodies to GAD RU, reference unit

JDF, Juvenile Diabetes Foundation

STU, standard titration unit

Received January 5, 1993; accepted July 20, 1993

Correspondence: Dr. Ian R. Mackay, Centre for Molecular Biology and Medicine, Monash University, Clayton, Victoria 3168, Australia.

Supported by grants from the National Health and Medical Research Council of Australia (M.J.R.), Nordisk, Australia (G.S.B.), the Cultural Foundation of Finland (T.T.), and Miles Diagnostics, West Haven, CT (P.Z.Z.). GAD-1 and GAD-6 were obtained from the Development Studies Hybridoma Bank, University of lowa, Iowa City, IA

' Present address: Fourth Department of Medicine, Helsinki University Hospital, Helsinki, Finland.
IDDM in most instances is the result of autoimmune destruction of insulin-producing $\beta$ cells in pancreatic islets (1). The specific antigen or antigens that are responsible for the $T$-cell and B-cell responses, and effector processes, are still unknown. The major serologic markers of IDDM include ICAb and antibodies to a $64-\mathrm{kD}$ antigen in pancreatic islet cells. Both ICAb and antibodies to the $64-\mathrm{kD}$ antigen can be detected in the majority of patients at the clinical onset of IDDM (2-5). However, antibodies to the 64-kD antigen can be detected earlier in the prodromal phase of IDDM than ICAb (3-6), and these correlate more closely with the progressive impairment of $\beta$-cell function than do ICAb (7).

Studies on antibodies to the $64-\mathrm{kD}$ antigen previously were limited because of technical difficulties with measurement of the antibodies. This antigen has now been identified as GAD (8), an enzyme that catalyzes the decarboxylation of glutamate to $\gamma$ aminobutyric acid, which is the major inhibitory neurotransmitter in the CNS. There are two isoforms of GAD with molecular masses of $65 \mathrm{kD}$ and $67 \mathrm{kD}(9-11)$. Outside the CNS, both forms of GAD have been found in pancreatic islet $\beta$-cells (11-13), wherein the catalytic product $\gamma$-aminobutyric acid may have a paracrine role $(14,15)$. The reported frequency of anti-GAD in patients with newly diagnosed IDDM of different ages varies from $22 \%$ to over $90 \%$, depending on the method used and the source of GAD (16-19).

Given the ethnic, geographic, and age-related differences in incidence of IDDM, and the possible decrease in antibody activity with duration of disease, studies on large groups of patients among different populations, with different ages and duration of disease, will be required to assess the actual diagnostic and pathogenetic significance of anti-GAD in IDDM. In a previous study, we measured anti-GAD in Australian adolescent and adult patients with IDDM (19), and here we report the frequency of anti-GAD in Western Australian children with newly diagnosed IDDM or IDDM of longer duration and in their family members using the same sensitive radioimmunoprecipitation assay with porcine brain GAD as antigen.

\section{MATERIALS AND METHODS}

Sera. Sera were obtained during 1985 to 1991 within 1 mo of the diagnosis of IDDM from 42 children $(21$ males and 21 females) attending Princess Margaret Hospital for Children in Perth, Western Australia, and in a 1991 family study from 22 families (three families had two affected children). The sera from the family study included sera from 25 children designated as probands including 21 ( 10 males and 11 females) with IDDM of 
longer duration (mean $\pm \mathrm{SD}, 4.8 \pm 3.3 \mathrm{yr}$ ), four (one male and three females) with IDDM of short duration (range $0-8 \mathrm{mo}$ ), and their 77 first-degree relatives. Clinical data on these subjects are shown in Table 1. Normal levels of anti-GAD for the immunoprecipitation assay were derived from tests on 76 Australian blood donors. Ethical approval for the study was given by the Research and Ethics Committee of the Princess Margaret Hospital for Children, Western Australia.

Radioimmunoprecipitation assay for anti-GAD. Anti-GAD were measured by an immunoprecipitation assay as described by Rowley et al. (19). In brief, GAD was purified from porcine brain by affinity chromatography and iodinated with ${ }^{125} \mathrm{I}$ using chloramine $\mathrm{T}$. After preabsorption with normal human pooled serum, the iodinated GAD ( ${ }^{125} \mathrm{I}-\mathrm{GAD}, 100000 \mathrm{cpm}$ ) was added to duplicate serum samples $[25 \mu \mathrm{L}$ in $25 \mu \mathrm{L}$ in a Tris-Triton buffer that contained Tris $20 \mathrm{mM}, \mathrm{NaCl} 150 \mathrm{mM}$, Triton X-100 $0.5 \%(\mathrm{wt} / \mathrm{vol}), \mathrm{pH} 7.4]$. After storage overnight at $4^{\circ} \mathrm{C}$, immune complexes were precipitated with protein A-Sepharose, and the radioactivity was measured. Each batch of sera tested included a positive reference serum, a high positive serum, a low positive serum, a known negative serum, and several sera from normal blood donors. Anti-GAD were expressed as designated RU by comparing counts precipitated by test sera at a dilution of $1: 2$ with counts precipitated by the reference serum defined to contain $100 \mathrm{RU}$ of activity. Sera with a positive test for anti-GAD were titrated to end point using a 2-fold dilution for those sera with less than $80 \mathrm{RU}$ and a 5-fold dilution for those sera with 80 RU or greater; accordingly, levels of anti-GAD were defined as STU, derived by the multiple of the number of RU at the titration end point and the actual titer as follows: $S T U=(R U \times$ titer $) \div$ 2 . The reason for division by 2 is that the standard serum used to derive RU is at a 2-fold dilution. Thus, in Results, sera with a positive test for anti-GAD were cited in STU and sera with a negative test for anti-GAD were cited in RU.

Immunoblotting. Immunoblotting was performed to characterize the GAD preparation used in our assays. The purified porcine brain GAD was dissolved in sample buffer containing $64 \mathrm{mM}$ Tris- $\mathrm{HCl}$, pH $6.8,2.0 \%$ SDS, $10 \%$ glycerol, and $5 \%$ mercaptoethanol. The samples were boiled for $2 \mathrm{~min}$ and separated by $10 \%$ SDS-PAGE. The protein was electrotransferred onto a nitrocellulose membrane and blocked using 5\% skimmed milk powder in PBS, pH 7.4. The nitrocellulose membrane was exposed to GAD-6, a mouse MAb to GAD65 (10), or K-2 (Chemicon Inc., Temecula, CA), a rabbit polyclonal antibody to GAD67 (9), and a normal human serum (1:200). GAD-6 was ascites fluid, diluted at 1:400, and $\mathrm{K} 2$ was diluted at 1:200. Antibodies bound to GAD were detected using an appropriate second antibody conjugated with horseradish peroxidase, either anti-mouse, anti-rabbit immunoglobulin or anti-human IgG (Silenus Labs, Victoria, Australia). The reaction was visualized with enhanced chemiluminescence using a commercial kit (Amersham, Buckinghamshire, UK).

Autoradiography. ${ }^{125}$ I-GAD used in the immunoprecipitation assay and pellets, which contained antigen-antibody complexes from four sera from patients with IDDM and a known negative serum after the assay, were separated by SDS-PAGE as described

Table 1. Clinical data on children with newly diagnosed IDDM and on probands with IDDM of longer duration and their first-degree relatives

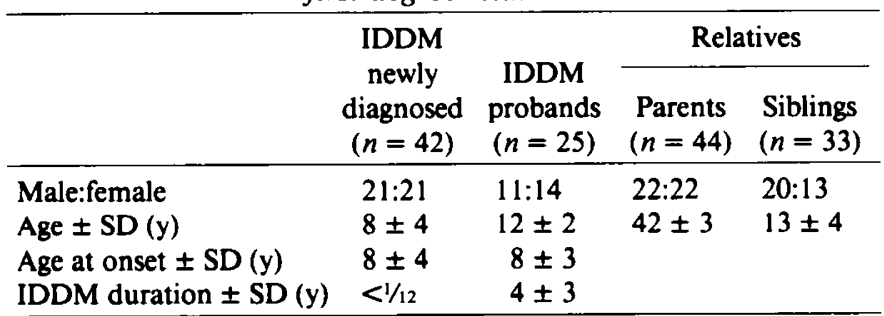

above, and the gel was fixed, dried, and exposed to x-ray film for $14 \mathrm{~d}$.

Inhibition of immunoprecipitation. To demonstrate the specificity of the binding of radioactivity in the immunoprecipitation assay, a serum was tested in the assay as described above but with the addition of about $0.05-6 \mathrm{ng}$ of purified, nonlabeled GAD as inhibitor. The highest amount of the nonlabeled GAD added represented approximately 10 times the amount of ${ }^{125} \mathrm{I}$ GAD applied to the sample in the immunoprecipitation.

Test for ICAb. ICAb were detected by indirect immunofluorescence using cryostat sections from a blood group $O$ human pancreas (20). Results were expressed as JDF units based on a standard laboratory reference serum that contained $80 \mathrm{JDF}$ units of ICAb. Any serum with a reactivity equal to or greater than 5 JDF units was scored as positive.

$H L A-D Q$ genotyping. Patients were typed only for HLA-DQ alleles, inasmuch as DQ products appear to represent the primary HLA association in IDDM. HLA-DQB1 typing was performed according to restriction fragment length polymorphism after enzymatic digestion of DNA and, in instances in which restriction fragment length polymorphism typing was ambiguous, confirmation was sought by amplification of DNA by the polymerase chain reaction and probing with type-specific oligonucleotides. The procedures were as described by Serjeantson et al. $(21,22)$.

Statistical analysis. The tests for statistical significance included the Mann-Whitney $U$ test, the $\chi^{2}$ test, or Fisher's exact test, as indicated.

\section{RESULTS}

Assay characteristics. Using immunoblotting with monoclonal mouse and polyclonal rabbit antibodies, the purified porcine brain GAD was shown to contain two isoforms, GAD65 and GAD67 (Fig. 1 $A$ ). After electrophoresis and autoradiography, the ${ }^{125}$ I-GAD used for immunoprecipitation gave a strong signal on the range of $50-80 \mathrm{kD}$, with individual proteins not identifiable (Fig. $1 B$, lane 1 ). ${ }^{125} \mathrm{I}-\mathrm{GAD}$ that was precipitated by four IDDM sera apparently reacted with the lower molecular mass component of GAD molecules (as judged by comparison with lane 1 in panel B).

In the inhibition-immunoprecipitation assay, the binding of serum antibody to ${ }^{125} \mathrm{I}-\mathrm{GAD}$ was inhibitable with nonlabeled

B

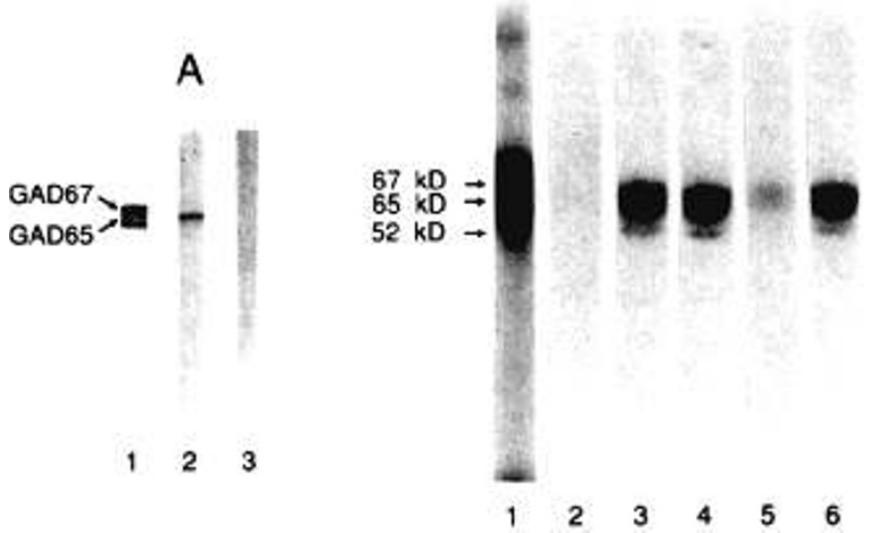

Fig. 1. Reactions of GAD with animal and human antibodies. $A$, Reaction of GAD $(0.5 \mu \mathrm{g})$ with a rabbit polyclonal antibody (K2, 1:200) raised against recombinant GAD67 (lane 1), a mouse MAb (GAD-6, 1:400) raised against GAD and specific to GAD65 (lane 2), and a normal human serum (1:200, lane 3). B, ${ }^{125}$ I-GAD separated by SDS-PAGE under reducing conditions and processed for autoradiography: ${ }^{125}$ I-GAD used in the immunoprecipitation assay (lane l), ${ }^{125} \mathrm{I}-\mathrm{GAD}$ exposed to a negative control serum (lane 2), and ${ }^{125}$ I-GAD precipitated by four sera from patients with IDDM (lanes 3-6). 
GAD, and the inhibitory effect was dose dependent, i.e. inhibition increased with increasing concentrations of nonlabeled GAD, up to $80 \%$ inhibition (Fig. 2). The remaining $20 \%$ reactivity, at the final level of inhibition, corresponded to about 200 $\mathrm{cpm}$, approximately the level of binding obtained with the known negative serum (see below).

The mean (range) $\mathrm{cpm}$ precipitated by the positive reference serum was 2900 (1400-4600), and that by the known negative serum was 190 (60-390), for 23 separate assays. To allow comparison between assays, the positive reference serum was used as a correction factor. The coefficients of variation for interassay and intraassay replicates for a high positive control serum (100 RU) were $9 \%(n=13)$ and $7 \%(n=20)$, respectively, and for a low positive control serum (30 RU) were $14 \%(n=13)$ and $8 \%$ $(n=20)$, respectively. The levels of anti-GAD in the 76 blood donors ranged from 4 to $18 \mathrm{RU}$ and were normally distributed with mean $( \pm S D)$ of $9( \pm 3)$ RU. Thus, 18 RU, which corresponds to the mean $\pm 3 \mathrm{SD}$, was used to define the upper normal limit.

The levels of anti-GAD for three positive sera and one negative serum titrated using 2-fold dilutions were plotted against the volumes of the sera used in the immunoprecipitation assay. Below approximately 80 RU of activity, there was a linear increase in the units of anti-GAD precipitated with increasing serum concentrations, i.e. the cpm precipitated were proportional to the amount of antibody. However, a plateau was reached at around $100 \mathrm{RU}$ (Fig. 3), indicative of a limiting amount of immunoreactive antigen in the preparation of ${ }^{125}$ IGAD. This was confirmed by serial titration of sera with a positive test for anti-GAD for which the titers ranged from 1:2 to 1:6250. According to the calculation (see Materials and Methods) for expressing reactivity, sera with a positive test for antiGAD ranged from 19 to 875000 STU of anti-GAD in the immunoprecipitation assay.

Anti-GAD in children with diabetes and relatives. The frequency of anti-GAD in children with newly diagnosed IDDM was $74 \%$ ( 31 of 42 ), and the mean level of anti-GAD was 7057 STU with a range of 19 to 875000 STU. The frequency and levels of anti-GAD were not significantly different from those for probands with a longer disease duration [67\% (14 of 21)], with mean of 2050 STU and a range of 30 to 16250 STU. There were four probands with a short duration of IDDM and all were positive for anti-GAD.

One of the 44 parents (2\%) and two of the 33 siblings (6\%) gave a positive result for anti-GAD; thus, the overall frequency

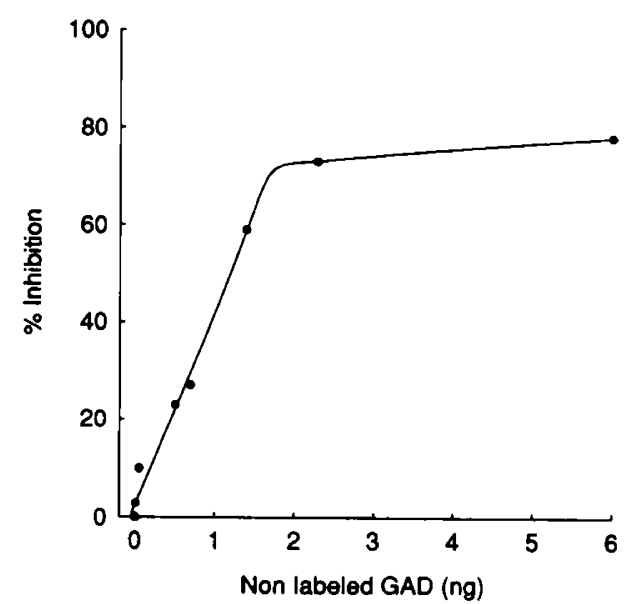

Fig. 2. Inhibition by nonlabeled GAD of reactivity between antiGAD and ${ }^{125} \mathrm{I}-\mathrm{GAD}$. The formula to calculate the $\%$ inhibition was $(A-P)+A \times 100$, where $A$ is cpm precipitated by an IDDM serum from $100000 \mathrm{cpm}$ of ${ }^{125} \mathrm{I}-\mathrm{GAD}$ in the absence of nonlabeled GAD and $P$ is $\mathrm{cpm}$ precipitated by the same serum from $100000 \mathrm{cpm}$ of ${ }^{125}$ I-GAD in the presence of varying amounts of nonlabeled GAD. The IDDM serum was at a final dilution of $1: 100$ at which it contained 70 STU of activity.

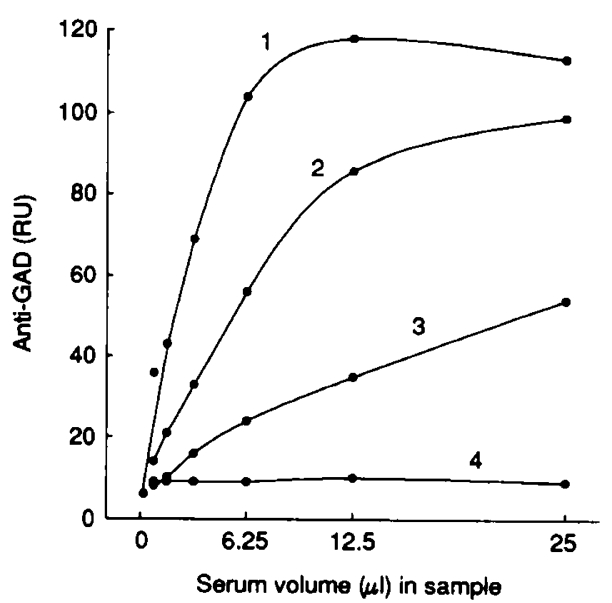

Fig. 3. Linearity between units of anti-GAD and amount of IDDM sera. Serum volumes from $25 \mu \mathrm{L}$ to $\sim 0.2 \mu \mathrm{L}$ (2-fold dilutions) in a sample volume of $50 \mu \mathrm{L}$ were mixed with $40 \mu \mathrm{L}$ of ${ }^{125}$ I-GAD (100000 $\mathrm{cpm}$ ) and tested by immunoprecipitation. The plot is linear up to approximately $80 \mathrm{RU}$ of activity for two high positive sera (lines $l$ and 2 ) and is linear for a low positive serum (line 3): line 4 is a normal control.

among first-degree relatives was $4 \%$ (three of 77). One relative with anti-GAD (13750 STU) was a 35-yr-old mother with two children with IDDM; her 11-yr-old daughter had been diagnosed 2 y earlier, and her 9-yr-old daughter only a few days earlier, and their levels of anti-GAD were 950 STU and 46 STU, respectively. The second relative with anti-GAD (60 STU) was a 13-yr-old girl with an 11-yr-old brother with IDDM for $1 \mathrm{y}$ whose level of anti-GAD was 675 STU. The third relative, with a minimally raised level of anti-GAD (22 STU), was a 9-yr-old boy whose 11 yr-old sister had IDDM for 6 y and was negative for anti-GAD. For the remainder of the relatives, the mean $( \pm S D)$ units of antiGAD were $7( \pm 2) \mathrm{RU}$, range 4 to $12 \mathrm{RU}$.

$I C A b$. The frequency of ICAb was $64 \%$ (27 of 42 ; range 5320 JDF units) in children with newly diagnosed IDDM and only $14 \%$ (three of 21 ; range 5-40 JDF units) in probands with a longer duration of IDDM. Three of the four probands with IDDM of short duration were positive for ICAb. All 77 firstdegree relatives were negative for ICAb.

Concordance of anti-GAD and ICAb. For newly diagnosed IDDM, the sensitivity of a positive test for anti-GAD and for ICAb was high, inasmuch as $90 \%$ of 42 children were positive for either or both. However, although there was considerable overlap in the antibody reactivity (Fig. 4), the two antibody populations appeared to be independent; the frequency of a positive test for ICAb among the case subjects positive for antiGAD was $65 \%$, which was similar to the frequency for case subjects negative for anti-GAD, $63 \%$.

Also, the frequency of anti-GAD was similar among the case subjects that were positive or negative for ICAb, $74 \%$ and $73 \%$, respectively; however, nearly all the case subjects with a strongly positive test for ICAb ( $\geq 40$ JDF units) were positive for antiGAD (Fig. 5). The frequency and levels of both anti-GAD and ICAb were higher in females than in males (Fig. 5).

For the probands with longer duration IDDM, females (mean age $\pm \mathrm{SD}, 9.1 \pm 2.5 \mathrm{y}$ ) compared with males (mean age $\pm \mathrm{SD}$, $6.8 \pm 3.8 \mathrm{y}$ ) tended to have higher frequencies of anti-GAD (nine of 11 versus five of 10 ) and levels of anti-GAD (mean 2560 STU, range 41-16 250 STU versus mean 1137 STU, range 30-3500 STU), but the differences were not statistically significant. The three case subjects with a positive test for ICAb among the probands with longer duration IDDM were also positive for antiGAD and were females. There was no obvious effect of age at onset on the frequency and levels of anti-GAD or ICAb in the patients with newly diagnosed IDDM or longer duration IDDM (data not shown). 

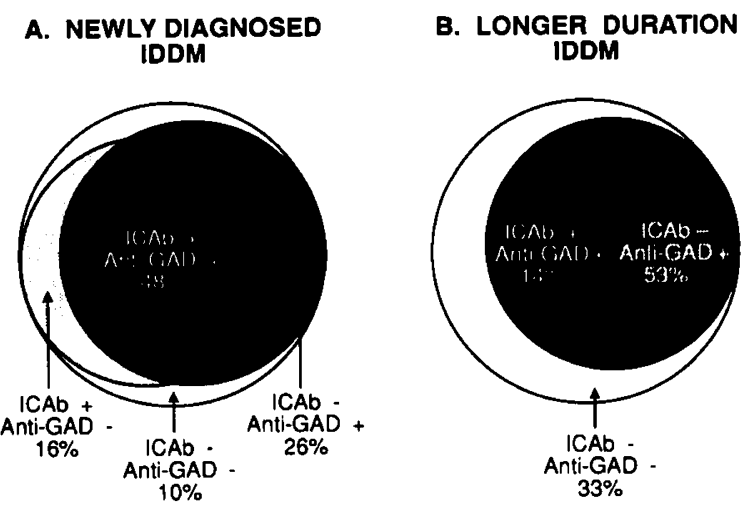

All subjects: A, 42 cases; B, 21 cases.

ICAb positive: A, 27 cases (64\%); B, 3 cases (14\%).

Anti-GAD positive: A, 31 cases (74\%); B, 14 cases $(67 \%)$.

Anti-GAD, ICAb positive: A, 20 cases (48\%); B, 3 cases (14\%).

Fig. 4. Frequency of ICAb and/or anti-GAD in children with newly diagnosed IDDM $(A)$ or IDDM of longer duration $(B)$.

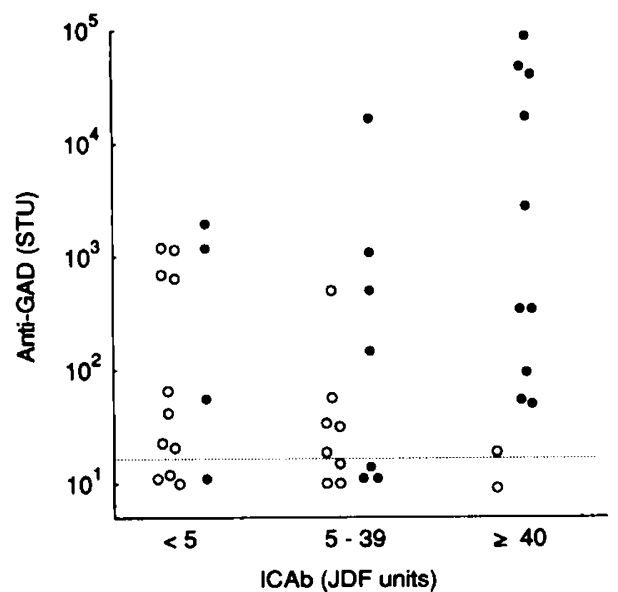

Fig. 5. The distribution of anti-GAD in children with newly diagnosed IDDM who were positive or negative for ICAb. $\bigcirc$, Male; $\odot$, female. The upper limit of normal for anti-GAD is indicated by the broken line. The mean levels of anti-GAD were significantly higher in females (12 707 STU, range 39-87 500 STU) than in males (322 STU, range 19-1200 STU; $p=0.005$, Mann-Whitney $U$ test) among all anti-GAD positive cases. Also, ICAb were more frequent in females ( 17 of 21 cases, $81 \%$ ) than in males ( 10 of 21 cases, $48 \% ; p=0.026$, Fisher's exact test).

Anti-GAD and $H L A-D Q B I$ alleles. For the family study, the distributions of the high-risk HLA-DQB1 alleles and the levels of anti-GAD among probands with IDDM that were positive or negative for anti-GAD and their first-degree relatives are shown in Table 2. Because 24 of the $25(96 \%)$ probands presented HLADQB $1{ }^{*} 0201$ and/or ${ }^{*} 0302$, an association between a positive test for anti-GAD and these alleles could not be ascertained. The frequency of HLA-DQB $1^{*} 0201 /{ }^{*} 0302$ heterozygosity in IDDM probands was significantly higher than that in their first-degree relatives $\left(p<0.001, \chi^{2}\right.$ test $)$. The higher frequency of HLA$\mathrm{DQB} 1{ }^{*} 0201 /{ }^{*} 0302$ heterozygosity in the anti-GAD positive relatives (two of three) than that in the anti-GAD negative relatives (six of 74) was significant ( $p=0.027$, Fisher's exact test). The distribution of HLA alleles appeared not to account for the female excess in frequencies of anti-GAD or ICAb in the probands.

\section{DISCUSSION}

In the present study, we measured anti-GAD by an immunoprecipitation assay. The preparation of purified porcine brain
GAD that was used contained two isoforms, GAD65 and GAD67, according to immunoblotting using standard marker antibodies for these two isoforms. Similar results were obtained by analysis and sequencing of proteins that were eluted from two-dimensional SDS-PAGE preparations (23). Although the proportions of GAD65 and GAD67 precipitated by the antibodies in IDDM sera were not ascertained in this study, it is known that antibodies in such sera may react with either one or both isoforms (16). However, it appeared from our study that the 65$\mathrm{kD}$ isoform was the main reactant, as found also by others (13). It was shown that iodinated GAD and nonlabeled GAD were antigenically similar using inhibition of the immunoprecipitation assay, wherein nonlabeled GAD inhibited the binding of antiGAD to ${ }^{125} \mathrm{I}-\mathrm{GAD}$ in a dose-dependent manner. This inhibitory effect validated the specificity of binding of anti-GAD to the ${ }^{125} \mathrm{I}$ GAD in our assay.

The study population, children with IDDM and their firstdegree relatives, were from Perth in Western Australia, which is an area with a midrange of IDDM incidence for the world (13.2 per 100000 persons/y) (24). Seventy-four percent of children with newly diagnosed IDDM had anti-GAD. The frequency of anti-GAD was similar to that found in Australian adult patients with IDDM $(19,25)$ and was similar to the frequency of antibodies to the $64-\mathrm{kD}$ autoantigen in previous studies $(4,26)$. In agreement with previous findings $(2,27)$, the titer and prevalence of ICAb decreased with increasing duration of disease; $64 \%$ of children with newly diagnosed IDDM were positive for ICAb in contrast to $14 \%$ of those with IDDM of longer duration. However, there was no significant difference in the frequency or the levels of anti-GAD according to disease duration. Anti-GAD persists in the majority of patients for up to 10-20 y after diagnosis $(19,26)$, albeit with some decrease in antibody frequency (22), although this was not observed in the present study. The persistence of anti-GAD in patients with IDDM even after presumed destruction of most if not all pancreatic islet $\beta$-cells is noteworthy. This may reflect either the existence of some GAD in residual islet cell tissue (28), ongoing autoantigenic stimulation by GAD in extrapancreatic sites, or conceivably stimulation by exogenous antigens that have some structural homology with GAD.

Immunotrapping enzyme activity assays have shown that antiGAD are demonstrable mostly in sera with higher titers of ICAb $(6,17,18)$. Similarly, we found that nearly all patients with high titers of ICAb had anti-GAD, but patients with high levels of anti-GAD did not necessarily have ICAb. Although anti-GAD and ICAb appear to be independent populations of antibodies, anti-GAD would contribute in part to ICAb activity, because ICA $b$ activity could be removed by preabsorption of sera with a rat brain homogenate that contained GAD (29).

Gender differences in the frequency of autoimmune diseases are of interest. The frequency is mostly greater in females, which is attributable to hormonal effects that would operate after puberty. Autoimmune diabetes is exceptional, with males predominating slightly, perhaps because of the onset of disease in childhood. In regard to autoantibodies, anti-GAD and ICAb in IDDM have a predominance in females when there is coexisting autoimmunity, clinical or serologic $(2,17,30)$. In the present study on children without other known autoimmune diseases, the levels of anti-GAD and the frequency of ICAb were greater in females than males; there appeared to be no obvious influence of age at onset or distribution of HLA alleles on the higher levels of anti-GAD and higher frequency of ICAb in females. The higher frequency in our study of levels of anti-GAD and ICAb in girls might be an artifact related to the small number of cases studied; however, the frequency in IDDM of ICAb is reported to be significantly higher in females than in males, at least when the onset of IDDM is after the age of $30 \mathrm{y}(31)$, and we note a report of a nonsignificantly higher frequency in females than males with IDDM of autoantibodies to the $64-\mathrm{kD}$ antigen (32). Of interest, more girls than boys were diagnosed with IDDM 
Table 2. Distribution of HLA-DQBI alleles and levels, mean and range (in parentheses) or actual values of anti-GAD for anti-GAD-positive or anti-GAD-negative IDDM probands and their first-degree relatives

\begin{tabular}{|c|c|c|c|c|c|c|c|c|}
\hline \multirow[b]{3}{*}{ HLA-DQBI } & \multicolumn{4}{|c|}{ IDDM probands $(n=25)$} & \multicolumn{4}{|c|}{ Relatives $(n=77)$} \\
\hline & \multicolumn{2}{|c|}{$\begin{array}{l}\text { Anti-GAD positive } \\
(n=18)\end{array}$} & \multicolumn{2}{|c|}{$\begin{array}{l}\text { Anti-GAD negative } \\
\quad(n=7)\end{array}$} & \multicolumn{2}{|c|}{$\begin{array}{l}\text { Anti-GAD positive } \\
\quad(n=3)\end{array}$} & \multicolumn{2}{|c|}{$\begin{array}{c}\text { Anti-GAD negative } \\
(n=74)\end{array}$} \\
\hline & $n: \%$ & STU & $n: \%$ & RU & $n: \%$ & STU & $n: \%$ & RU \\
\hline${ }^{*} 0201 /{ }^{*} 0302 *$ & $8: 44$ & $1168(46-3500)$ & $4: 57$ & $10(7-17)$ & $2: 67$ & 60,13750 & $6: 8$ & $9(7-11)$ \\
\hline${ }^{*} 0201 /{ }^{*} 0201$ & $4: 22$ & $819(600-1050)$ & $0: 0$ & 0 & $0: 0$ & 0 & $10: 13$ & $8(4-12)$ \\
\hline *0201/X† & $2: 11$ & 53,1503 & $2: 29$ & 9,12 & $1: 33$ & 22 & 19:26 & $8(5-11)$ \\
\hline "0302/X & $3: 17$ & $30,41,16250$ & $1: 14$ & 15 & $0: 0$ & 0 & $19: 26$ & $5(4-11)$ \\
\hline $\mathrm{X} / \mathrm{X}$ & $1: 6$ & 850 & $0: 0$ & 0 & $0: 0$ & 0 & $20: 27$ & $7(5-11)$ \\
\hline
\end{tabular}

* The frequency of HLA-DQB $1{ }^{*} 0201 /{ }^{*} 0302$ heterozygosity was higher in IDDM probands than in relatives $\left(p<0.001, \chi^{2}\right.$ test $)$ and was also higher in anti-GAD-positive relatives than in anti-GAD-negative relatives $(p=0.027$, Fisher's exact test).

$+X$ represents the following HLA-DQB1 alleles: ${ }^{*} 0303,{ }^{*} 0402,{ }^{*} 0501,{ }^{*} 0503,{ }^{*} 0602,{ }^{*} 0603$, and ${ }^{*} 0604$.

from 1985 to 1989 in Western Australia from where our sera originated (24).

The presence of anti-GAD or ICAb in healthy persons may be a sign of ongoing destruction of islet cells and, at this stage, intervention could halt the autoimmune process. Positivity for ICAb denotes an increased but not absolute risk of developing IDDM, whether or not any family member has IDDM: the predictive value of ICAb is especially high in first-degree relatives of patients with IDDM. In different studies, the frequency of ICAb in first-degree relatives of patients with IDDM has ranged from 0.9 to $6 \%(33-35)$. The risk of developing IDDM in firstdegree relatives of patients with IDDM has been estimated to be about $1 \%$ in those negative for ICAb, compared with $40-70 \%$ in those positive for ICAb, depending on the titer of $\operatorname{ICAb}(26,35$, 36). ICAb were not detected in any of the first-degree relatives in our study, presumably because of the relatively small number of subjects tested. However, the frequency of anti-GAD was $2 \%$ in parents and $6 \%$ in siblings of children with IDDM.

Concordance rates of IDDM are about $36 \%$ in identical twins (37) and $15 \%$ in HLA-identical siblings (38). These low rates, together with marked geographic differences in incidence and prevalence of IDDM (39), clearly indicate that environmental as well as genetic factors contribute to the pathogenesis of IDDM. In Caucasians, the HLA-associated DQ genotypes DQB1*0302 and $\mathrm{DQB} 1{ }^{*} 0201$, together with DR3 and DR4, are associated with $\operatorname{IDDM}(38,40)$. Moreover, each of the genotypes has been linked to an increased prevalence of anti-GAD in Caucasian patients with $\operatorname{IDDM}(21,22)$. In the present study, most probands had these high-risk genotypes, and the frequency of HLADQB $1{ }^{*} 0201 /{ }^{*} 0302$ heterozygosity was significantly higher in the probands than in the relatives. The HLA-DQB $1^{*} 0201 /{ }^{*} 0302$ heterozygosity was also observed to be higher in anti-GADpositive relatives than in anti-GAD-negative relatives, but we recognize the small number of cases available for analysis, and more relatives are being recruited to reexamine this finding.

In conclusion, testing for anti-GAD could provide a highly discriminatory ascertainment of risk for IDDM (18), especially if used together with detection of ICAb and high-risk genotypes (41). This will be increasingly relevant with the development of immunologically based interventions at the preclinical stage of IDDM.

\section{REFERENCES}

1. Hagopian W, Lernmark $\dot{A} 1992$ Autoimmune diabetes mellitus. In: Rose NR, Mackay IR (eds) Autoimmune Disease II. Academic Press. Orlando, FL, pp 235-278

2. Lendrum R, Walker G, Cudworth AG, Theophanides C, Pyke DA, Bloom A Gamble DR 1976 Islet-cell antibodies in diabetes mellitus. Lancet 2:12731276

3. Bækkeskov S, Nielsen JH, Marner B, Bilde T, Ludvigsson J, Lernmark Ȧ 1982 Autoantibodies in newly diagnosed diabetic children immunoprecipitate human pancreatic islet cell proteins. Nature 298:167-169

4. Bzkkeskov S. Landin M, Kristensen JK, Srikanta S, Bruining GJ, MandrupPoulsen T, de Beaufort C, Soeldner JS, Eisenbarth G, Lindgren F, Sundquist $G$, Lernmark $\dot{A} 1987$ Antibodies to a $64,000 \mathrm{M}$, human islet cell antigen precede the clinical onset of insulin-dependent diabetes. J Clin Invest 79:926934

5. Atkinson MA, Maclaren NK, Scharp DW, Lacy PL, Riley WJ 199064,000 Mr autoantibodies as predictors of insulin-dependent diabetes. Lancet 335:13571360

6. Seissler J, Hering B, Richter W, Glück M. Yassin N, Bretzel RG, Boehm BO, Federlin K, Scherbaum WA 1992 Antibodies to the M, 64,000 (64K) protein in islet cell antibody positive non-diabetic individuals indicate high risk for impaired beta-cell function. Diabetologia 35:550-554

7. Bärmeier H, McCulloch DK. Neifing JL, Warnock G, Rajotte RV, Palmer JP, Lernmark $\dot{A} 1991$ Risk for developing type I (insulin-dependent) diabetes mellitus and the presence of islet $64 \mathrm{~K}$ antibodies. Diabetologia 34:727-733

8. Bakkeskov S, Aanstoot H-J, Christgau S, Reetz A, Solimena M, Cascalho M Folli F, Richter-Olesen H, de Camilli P 1990 Identification of the 64K autoantigen in insulin-dependent diabetes as the GABA-synthesising enzyme glutamic acid decarboxylase. Nature 347:151-156

9. Kaufman DL, Houser CR, Tobin AJ 1991 Two forms of the $\gamma$-aminobutyric acid synthetic enzyme glutamate decarboxylase have distinct intraneuronal distributions and cofactor interactions. J Neurochem 56:720-723

10. Chang YC, Gottlieb DI 1988 Characterization of the proteins purified with monoclonal antibodies to glutamic acid decarboxylase. J Neurosci 8:21232130

11. Erlander MG, Tillakaratne NJK, Feldblum S. Patel N, Tobin AJ 1991 Two genes encode distinct glutamate decarboxylase. Neuron 7:91-100

12. Christgau S, Schierbeck H, Aanstoot HJ, Aagaard L, Begley K, Kofod H, Hejnaes K, Bækkeskov S 1991 Pancreatic $\beta$ cells express two autoantigenic forms of glutamic acid decarboxylase, a $65-\mathrm{kDa}$ hydrophilic form and a $64-$ $\mathrm{kDa}$ amphiphilic form which can be both membrane-bound and soluble. J Biol Chem 266:21257-21264

13. Hagopian WA, Michelsen B, Karlsen AE, Larsen F, Moody A, Grubin CE Rowe R, Petersen J. Mcevoy R. Lernmark $\dot{A} 1993$ Autoantibodies in IDDM primarily recognize the $65,000-\mathrm{M}_{\mathrm{r}}$ rather than the $67,000-\mathrm{M}_{\mathrm{r}}$ isoform of glutamic acid decarboxylase. Diabetes 42:631-636

14. Rorsman P, Berggren PO. Bokvist K. Ericson H. Möhler H. Östensön CG Smith PA 1989 Glucose-inhibition of glucagon secretion involves activation

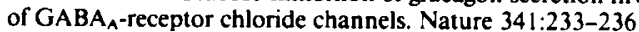

15. Reetz A. Solimena M, Matteoli M, Folli F, Takei K, de Camilli P 1991 GABA and pancreatic beta-cells: co-localization of glutamic acid decarboxylase $(G A D)$ and GABA with synaptic-like microvesicles suggests their role in GABA storage and secretion. EMBO J 10:1275-1284

16. Kaufman DL, Eriander MG, Clare-Salzler M, Atkinson MA, Maclaren NK Tobin AJ 1992 Autoimmunity to two forms of glutamate decarboxylase in insulin-dependent diabetes mellitus. J Clin Invest 89:283-292

17. Martino GV, Tappaz ML, Braghi S, Dozio N, Canal N, Pozza G. Bottazzo GF, Grimaldi LME, Bosi E 1991 Autoantibodies to glutamic acid decarboxylase (GAD) detected by an immuno-trapping enzyme activity assay: relation to insulin-dependent diabetes mellitus and islet cell antibodies. J Autoimmun to insulin-dept

18. Thivolet CH, Tappaz M, Durand A, Petersen J, Stefanutti A. Chatelain P, Vialettes B, Scherbaum W, Orgiazzi J 1992 Glutamic acid decarboxylase (GAD) autoantibodies are additional predictive markers of type 1 (insulin dependent) diabetes mellitus in high risk individuals. Diabetologia 35:570576

19. Rowley MJ, Mackay IR, Chen Q-Y, Knowles WJ. Zimmet PZ 1992 Antibodies to glutamic acid decarboxylase discriminate major types of diabetes mellitus. Diabetes 41:548-551

20. Bakos S, Mackay IR, Rowley MJ, Knowles W, Zimmet P 1991 Islet cell antibodies and other markers of autoimmunity and diabetes mellitus in Nauruans. Diabetologia 34:796-800

21. Serjeantson SW, Kohonen-Corish MJ, Rowley MJ, Mackay IR, Knowles WJ, 
Zimmet P 1992 Antibodies to glutamic acid decarboxylase are associated with HLA-DR genotypes in both Australian and Asian insulin-dependent diabetes mellitus patients. Diabetologia 35:996-100।

22. Serjeantson SW, Court J, Mackay IR, Matheson B, Rowley MJ, Tuomi T, Wilson D, Zimmet P 1993 HLA-DQ genotypes are associated with autoimmunity to glutamic acid decarboxylase in insulin dependent diabetes mellitus patients. Human Immunol (in press)

23. Tuomi T, Rowley MJ, Knowles WJ, Chen Q-Y, McAnally T, Zimmet PZ, Mackay IR 1993 Autoantigenic properties of native and denatured glutamic acid decarboxylase: evidence for a conformational epitope. Clin Immunol Immunopathol (in press)

24. Kelly H, Byrne GC 1992 Incidence of IDDM in Western Australia in children aged 0-14 yr from 1985 to 1989. Diabetes Care 15:515-517

25. Zimmet P. Rowley MJ, Mackay IR, Knowles WJ, Chen Q-Y, Chapman LH, Serjeantson SW 1993 The ethnic distribution of antibodies to glutamic acid decarboxylase: presence and levels in insulin-dependent diabetes mellitus in Europid and Asian subjects. J Diabetic Complications 7:1-7

26. Christie MR, Daneman D, Champagne P. Delovitch TL 1990 Persistence of serum antibodies to $64000-\mathrm{M}_{\mathrm{r}}$ islet cell protein after onset of type 1 diabetes. Diabetes 39:653-656

27. Kolb H, Dannehl K, Grüneklee D, Zielasek J, Bertrams J, Hübinger A, Gries FA 1988 Prospective analysis of islet cell antibodies in children with type 1 (insulin dependent) diabetes. Diabetologia 31:189-194

28. Gepts W, de Mey J 1987 Islet cell survival determined by morphology: an immunocytochemical study of the islets of Langerhans in juvenile diabetes mellitus. Diabetes 27:25!-261

29. Genovese S, Bonifacio E. McNally JM, Dean BM, Wagner R, Bosi E. Gale EAM. Bottazzo GF 1992 Distinct cytoplasmic islet cell antibodies with different risks for type 1 (insulin-dependent) diabetes mellitus. Diabetologia 35:385-388

30. Bottazzo GF, Cudworth AG, Moul DJ, Doniach D. Festenstein H 1978 Evidence for a primary autoimmune type of diabetes mellitus. $\mathrm{Br}$ Med J 2:1253-1255

31. Landin-Olsson M, Karlsson FA, Lernmark $\dot{A}$. Sundkvist G. and the Diabetes Incidence Study in Sweden Group 1992 Islet cell and thyrogastric antibodies in 633 consecutive 15- to 34-yr-old patients in the diabetes incidence study in Sweden. Diabetes 41:1022-1027
32. Christie M. Landin-Olsson M. Sundkvist G. Dahlquist G, Lernmark A, Bakkeskov $S 1988$ Antibodies to a $M_{r}-64000$ islet cell protein in Swedish children with newly diagnosed type 1 (insulin-dependent) diabetes. Diabetologia 31:597-602

33. Srikanta S, Ganda OP, Eisenbarth GS, Soeldner JS 1983 Islet cell antibodies and beta-cell function in monozygotic triplets and twins initially discordant for type I diabetes mellitus. N Engl J Med 308:322-325

34. Hägglot B. Rabinovitch A, Mackay P, Huen A, Rubenstein AH, Marner B, Nerup J, Lernmark $\dot{A} 1986$ Islet cell and other organ specific autoantibodies in healthy first degree relatives of insulin-dependent diabetic children. Acta Paediatr Scand 75:611-618

35. Riley WJ, Maclaren NK, Krischer J, Spillar RP. Silverstein JH, Schatz DA, Schwartz S. Malone J, Shah S, Vadheim C, Rotter JI 1990 A prospective study of the development of diabetes in relatives of patients with insulindependent diabetes. N Engl J Med 323:1167-1172

36. Thivolet C, Beaufrère B, Geburher L. Chatelain P. Orgiazzi J, Francois R 1991 Autoantibodies and genetic factors associated with the development of type 1 (insulin-dependent) diabetes mellitus in first degree relatives of diabetic patients. Diabetologia 34:186-191

37. Olmos P, A'Hern R, Heaton DA, Millward BA, Risley D, Pyke DA, Leslie RDG 1988 The significance of the concordance rate of type 1 (insulindependent) diabetes in identical twins. Diabetologia 31:747-750

38. Thomson G. Robinson WP, Kuhner MK. Joe S, MacDonald MJ, Gottschall JL, Barbosa J. Rich SS, Bertrams J, Baur MP, Partanen J, Tait BD, Schober E. Mayr WR, Ludvigsson J, Lindblom B. Farid NR. Thompson C. Deschamps I 1988 Genetic heterogeneity, modes of inheritance, and risk estimates for a joint study of Caucasians with insulin-dependent diabetes mellitus. Am J Hum Genet 43:799-816

39. Zimmet $P 1991$ The epidemiology of diabetes mellitus and associated disorders. In: Alberti KGMM, Krall LP (eds) Diabetes Annual, Vol 6. Elsevier/North Holland Biomedical Press, Amsterdam, pp 1-19

40. Todd JA. Bell JI, McDevitt HO 1987 HLA-DQ $\beta$ gene contributes to susceptibility and resistance to insulin-dependent diabetes mellitus. Nature 329:599604

41. Deschamps I, Boitard C. Hors J, Busson M. Marcelli-Barge A. Mogenet A, Robert JJ 1992 Life table analysis of the risk of type I (insulin-dependent) diabetes mellitus in siblings according to islet cell antibodies and HLA markers. Diabetologia 35:951-957 